\title{
Sociobiology
}

RESEARCH ARTICLE - ANTS

\section{Ant Assemblage Structure in a Secondary Tropical Dry Forest: The Role of Ecological Succession and Seasonality}

\author{
T MARQUES ${ }^{1}$, MM ESPIRÍto-SANTO $^{2}$, FS NEVES $^{3}$, JH SCHOEREDER ${ }^{4}$ \\ 1 - Instituto Federal de Educação, Ciência e Tecnologia do Norte de Minas Gerais - Campus Salinas, Salinas-MG, Brazil \\ 2 - Universidade Estadual de Montes Claros, Campus Darcy Ribeiro, Montes Claros-MG, Brazil \\ 3 - Universidade Federal de Minas Gerais, Belo Horizonte-MG, Brazil \\ 4 - Universidade Federal de Viçosa, Viçosa-MG, Brazil
}

\section{Article History}

\section{Edited by}

Gilberto M. M. Santos, UEFS, Brazil

Received 14 December 2016

Initial acceptance 13 February 2017

Final acceptance 13 February 2017

Publication date 17 october 2017

\section{Keywords}

Formicidae; Spatial scales; Temporal

scales; $\beta$-diversity; Conservation

strategies.

\section{Corresponding author}

Tatianne Marques

Instituto Federal de Educação, Ciência

e Tecnologia do Norte de Minas Gerais

Fazenda Varginha Km 02

39560-000, Salinas-MG, Brasil.

E-Mail: tatianne.marques@ifnmg.edu.br

\begin{abstract}
This study identified the main biological mechanisms governing the diversity of ants on different ecological time scales. Ants were sampled in 15 plots distributed in early, intermediate and late stages of succession (five plots per stage) at the Parque Estadual da Mata Seca, Brazil. At each sample point, unbaited pitfall traps were installed in hypogaeic, epigaeic and arboreal strata. We collected 95 ant species from 26 genera and nine subfamilies. Our results indicated that there was an increase in species richness in advanced stages of succession. We also observed that ant assemblages were different among successional stages. For the arboreal and epigaeic strata, species richness did not change with succession progression, but species composition of these two strata differed among successional stages. Unlike to arboreal and epigaeic ants, hypogaiec ant species richness was higher in the intermediate and late stages of succession and the composition of hypogaeic ants differed among successional stages. Similarity between ant species foraging in arboreal and epigaeic strata decreases with succession progression and $\beta$-diversity was higher in advanced successional stages. Additionally, species richness was higher in the dry season, whereas the composition of ant assemblages did not change between seasons. A considerable fraction of the ant assemblage was found only in advanced stages of succession, demonstrating the importance of secondary habitats in maintaining biodiversity in dry forests.
\end{abstract}

\section{Introduction}

Species diversity can be influenced by processes acting at different spatial and temporal scales (Godfray \& Lawton, 2001). Spatial scales have received increased attention in the analysis of the relationship between biodiversity and changes in landscape structure (Ribas et al., 2003; Kalacska et al., 2004), although recently few studies focused on the effects of time scales. This shift in the focus of the studies occurred because the variation in the number of species in a landscape depends on the ecological processes that operate on multiple time scales (Lambi, 1996). Ecological succession and seasonality are processes that occur in different time scales and can influence the species diversity of a forest in different ways (Neves et al., 2014).
Two basic models of ecological succession have been described: assemblages controlled by dominance and assemblages controlled by foundation. In the first model, altered habitats will initially be colonized by pioneer species, which are later replaced by intermediate and climax species. This replacement occurs due to the niche requirements of the species and/or through competition, which is altered throughout the succession. In this model, there is a directional succession, and the species composition in the final stage is predictable (Dauber \& Wolters, 2004; 2005). In the assemblages governed by the foundation model, some species may colonize the altered environment while inhibiting, facilitating, or tolerating the establishment of other species. If the early colonizers inhibit the establishment of other species, the assemblage 
composition will remain the same throughout the succession process. This model is typically called "lottery model" (Yu et al., 2001). Conversely, if the initial species facilitate or tolerate the replacement of species, there will be change in the composition of species in the area.

Tropical Dry Forests (TDFs) have been subjected to intense and constant depletion because they are historically targeted for agriculture and human occupation (SanchezAzofeifa et al., 2005). These factors can increase the area of TDFs undergoing ecological succession. In this scenario, vegetation and environment change mutually during secondary succession and in turn also affect biota, for example, by influencing resource availability and interactions among organisms (Sousa-Souto et al., 2016). According to Ribas et al. (2002, 2003), competition is an important force that structures the ant assemblages which is regulated by habitat heterogeneity. However, some studies agree with a limited role of competition between ant species and pointed that environmental constraints may be more important for ant assemblages (Baccaro et al., 2011; Jacquemin et al., 2016). Elucidating the pattern of variation in the ant assemblages along the succession and to identify environmental variables that explain this variation consists of subjects which have been poorly documented (Sousa-Souto et al., 2016).

The seasonal changes that occur in the plant structure of TDFs influence different groups of animals and constitute another important temporal process. The main structural change of this ecosystem results from high foliar deciduousness, which is caused by a prolonged dry season that restricts the productivity of plants to the 3-5 months per year when rainfall is highly concentrated (Sanchez-Azofeifa et al., 2005). The seasonality of this forest affects the phenological patterns of plants, as well as the abundance, richness and composition of the associated fauna (Cuevas-Reyes et al., 2006). This explains why certain species may specialize in the use of resources under more severe conditions, resulting in a temporal variation of diversity and assemblages composition (Silva et al., 2014). According to Gove et al. (2005), the terrestrial ant richness increased in the dry season in Mexican TDF. In studies conducted in a Brazilian TDF, the arboreal ant species richness did not differ between seasons, but the abundance and richness of dung beetle species were higher in the wet season, and the composition of ant and dung beetles species changed between the seasons (Neves et al., 2010a,b).

Among the various organisms that could be used in diversity studies, ants are considered an excellent model because they are highly abundant, diverse and have a wide geographical distribution (Underwood \& Fisher, 2006). Moreover, ants occupy multiple trophic levels and contribute substantially to ecosystem functioning (Holldobler \& Wilson, 1990). In addition, the diversity of ants has been positively related to habitat complexity, as ant species richness increases with habitat heterogeneity and the availability of resources in tropical forests (Ribas et al., 2003; Ribas \& Schoereder, 2007;
Klimes et al., 2012). It is expected that land-use intensification of TDF may result in higher biotic homogenization (Solar et al., 2015), which will in turn, decrease $\beta$-diversity among forests within each succession stage.

In this study, we study the dynamics and structure of the ant assemblages at different time scales (ecological succession and seasonal variation). On the time scale for ecological succession, we tested the following hypotheses:

(1) Succession dynamics are controlled by dominance. Thus, the ant species richness is higher in more advanced stages of succession, possibly due to the competitive exclusion of pioneer species by specialist species, leading to a shift in assemblage composition.

(2) $\beta$-diversity is higher in advanced successional stages. With increasing environmental heterogeneity in succession process, there is a higher species turnover in these stages because ants occupy different spatial niches.

We measured variables that could estimate the availability of resources and habitat conditions for the ant assemblages in order to identify factors that could explain the diversity patterns found within the succession models.

On the time scale of seasonal variation, we tested the following hypothesis:

(3) Ant species richness is higher during the dry season and the composition of ant species changes between seasons.

\section{Material and Methods}

\section{Study area and sampling design}

The study was carried out at the Parque Estadual da Mata Seca (PEMS), a protected conservation area that was established by the expropriation of four farms in 2000 . The park is currently managed by the Instituto Estadual de Florestas. The PEMS has an area of 15,466.44 ha and is located in the middle São Francisco valley in the municipality of Manga, Minas Gerais

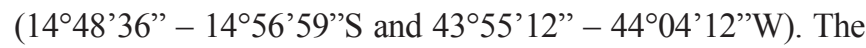
original vegetation of the park is TDF, which is dominated during the dry season by trees that are $90-95 \%$ deciduous (MayOctober) and grow on flat, nutrient-rich soil (Pezzini et al., 2014). The climate is considered tropical semi-arid (Köppen classification) and is characterized by a pronounced dry season during the winter. The region's average temperature is $24.4^{\circ} \mathrm{C}$, and the mean annual precipitation is $818 \pm 242 \mathrm{~mm}$ (Pezzini et al., 2014). The main economic activities in the PEMS area before the expropriation of the farms were the cultivation of bean and maize, as well as livestock. Approximately 1,525 ha $(15 \%)$ of the PEMS comprise abandoned pastures in different stages of succession.

In January 2006, 15 plots, each with an area of $20 \mathrm{x}$ $50 \mathrm{~m}$ (0.1 ha each), were installed in forest patches inside the PEMS. These plots were undergoing early, intermediate or late successional stages (five plots for each stage; Fig 1), as classified by the history of the land use (i.e., the time since the land was abandoned) and by the vertical (tree height, 
number of forest strata) and horizontal (density of trees) structures in the vegetation areas (Madeira et al., 2009). The early successional plots were used as pasture for at least 20 years and abandoned in 2000. They are characterized by herbaceous-shrubby vegetation with sparse trees forming a discontinuous canopy up to four meters in height. The intermediate successional plots were used as pasture for an unknown period and abandoned at the late 1980s. They have two vertical strata: the first is composed of 10-12 $\mathrm{m}$ tall deciduous trees and the second comprises a dense understory with many young trees and abundant lianas. The late successional plots have no records of clear-cutting for the last 50 years and are also have two strata. The first stratum is composed of deciduous trees that form a closed canopy 18-20 $\mathrm{m}$ high. The second stratum comprises a sparse understory of low liana density (see Madeira et al., 2009; Neves et al., 2014). Plots from the same regeneration stage were located in a sequence and ranged $0.2-1.0 \mathrm{~km}$ from each other. Plots were located along a $7 \mathrm{~km}$ transect encompassing all successional stages (Fig 1). The plots had similar topographical, soil and microclimate characteristics, which reduced the variation in physical conditions that could affect the succession process and chronosequence study (Vargas et al., 2008).

\section{Ant sampling}

Ants were sampling twice in each plot: in September 2008 (13.6 $\mathrm{mm}$ of rain), during the late dry season, and in February 2009 (247.5 mm of rain) at the onset of the wet season. In each of the five plots, five sampling points set 10 $\mathrm{m}$ apart were selected, representing a total of 25 points per stage. As different strata may have different ant assemblages (Schmidt \& Solar, 2010), unbaited pitfall traps were installed at each sample point in hypogaeic (underground), epigaeic (ground level) and arboreal strata, totaling 75 points overall ( 5 plots $\times 5$ sampling points $\times 3$ pitfall traps $=75$ ). Arboreal pitfalls were designed based on the description in Ribas et al. (2003), and epigaeic pitfall were similar to the arboreal pitfall but was buried so that the opening of the container was located at ground level. Hypogaeic pitfalls were designed according to Schmidt and Solar (2010). To test the completeness of the sampling, we calculated the adequacy of the sampling effort with a species accumulation curve, both in dry and wet season.

The traps in the epigaeic and arboreal strata were left in the field for $48 \mathrm{~h}$. The impact caused by soil disturbance and the lack of attraction bait could hinder the performance of subterranean traps. So, we increased the sampling time of this type of trap to $72 \mathrm{~h}$. This increased time would be also sufficient for the ants to reconstruct their tunnels (Schmidt \& Solar, 2010). After trap removal, ants were sorted and taken to the laboratory, where they were mounted and identified. Ants were sorted to genus and then to species or morphospecies and the similarity between epigaeic and arboreal ants (\%) was calculated for each of the 75 points. Ant nomenclature follows Bolton (2016). Voucher specimens are deposited at the reference collection at the Laboratorio de Ecologia de Comunidades at the Universidade Federal de Viçosa (UFV), in Viçosa, Brazil.



Fig 1. Map of the study region. In the detailed figure, square represent the landscape sampled at Parque Estadual da Mata Seca and sampling design of the 15 permanent plots. Circles represent plots distributed in early stages of succession; squares represent intermediate and triangles represent late stages of succession. 
Explanatory variables

We estimated variables that may represent the availability of resources and also the local conditions for the resident ants in each sampled stratum.

To estimate conditions and resource availability to arboreal antes, we used two surrogates. Basal circumferences of all trees found in a two-meter radius around each sample point were measured, as trees with higher basal circumferences occupy a larger area and could provide a higher number of nesting places (Siemann et al., 1999) for arboreal ants. Thus, these data yielded an estimate of the available resources for arboreal ants. Also, we obtained a digital image next to the tree where the arboreal pitfall of each sample point was installed. Images were taken using a Nikon Coolpix 4500 camera with a fish-eye lens attached, mounted on a leveled tripod at $1.5 \mathrm{~m}$ above the soil, with the fish eye focus set to infinity. The black and white images were taken in the late afternoon to avoid over-exposure from the midday sun. We used the software Gap Light Analyzer to measure the percentage of canopy cover from the resulting photos (Frazer et al., 1999). As photos were taken in the late dry season, at a time of canopy thinning, the canopy cover was estimated by the wood area that shades the forest floor. While acknowledging that this provided an underestimate of wet season canopy cover, this measure was used as an estimate of the climatic conditions of the stratum, because canopy cover can affect the availability of light and humidity in the understory. Areas with greater canopy cover may maintain a microclimate that is more suitable for arboreal ant species (Sousa-Souto et al., 2016).

We collected three $20 \times 20 \mathrm{~cm}$ samples of leaf-litter one meter away from each o epigaeic trap. These samples were mixed, packed in plastic bags and transported to the Community Ecology Laboratory (Laboratório de Ecologia de Comunidades) at the UFV. Leaf-litter was then transferred to paper bags and oven-dried at $60^{\circ} \mathrm{C}$ until constant litter weight. The dry weight was used to estimate the availability of resources for epigaeic ants because the leaf-litter serves as a source of food and provides possible nesting sites for ants (Muscardi et al., 2008). The percentage of canopy cover was also used as an estimate of abiotic conditions for epigaeic ants. The methodology was similar to the procedures conducted for the arboreal stratum, but the digital photographs were taken with the camera positioned at ground level close to the pitfall trap.

To estimate conditions and resource availability to hypogaeic ants, a soil sample was removed with a metal ring of known volume $\left(91.61 \mathrm{~cm}^{3}\right)$ to determine the moisture content, as well as the density and porosity of the soil at each collection point. These two estimates were used as surrogates of conditions of this stratum for resident ants. Schmidt et al. (2013) pointed soil density as determining factor for structure hypogaeic ant assemblages. The analyses were performed at the Soil Physics Laboratory (Laboratório de Física do Solo) at the UFV.

We measured the tree species richness assisted by experts. We counted the number of tree species with a circumference at breast height $(\mathrm{CBH})$ of more than $10 \mathrm{~cm}$ present in each plot of the successional stages in the TDF that was studied. Tree richness was used as an estimate of the soil conditions for ants in all strata because the physical structure of soil is modified by the establishment of plant species in the area (Sagar \& Verma, 2010).

\section{Data analyses}

The data on the ants sampled in the dry season were used to test the first two hypotheses, concerning ecological succession. The sampling carried out during the wet season did not include the estimation of explanatory variables, it was used only to compare the ant assemblages in two different seasons. We constructed the species accumulation curves using the numbers of species and the number of pitfall traps sampled in different seasons, performing 10000 randomizations with replacement to generate confidence intervals using the vegan package in $\mathrm{R}$ 3.1.2 software (R Development Core Team, 2014).

Due to variation in behavior of individual species and their interactions with the environment, any biodiversity sampling method must face the issue of underestimating true species richness. For this reason, estimation techniques are often used in diversity studies, particularly in samples taken over brief periods of time (Gotelli et al., 2011). We used the sample-based species estimator first-order Jackknife to estimate ant species number at each successional stage, stratum and season (Appendix S1). These analyses were performed from presence/absence matrices. Jackknife estimators provide the most accurate estimates of the true value of species richness observed in the site (Gotelli \& Colwell, 2011). The Jack1 estimator has performed consistently well in comparisons of various estimators of species richness, and is widely used for estimating species richness (Gotelli \& Colwell, 2011). Moreover, the Jack1 estimator provides reliable estimates of local species richness even when habitats are heterogeneous within sampling units. Calculations were performed using EstimateS software (Colwell, 2006).

$\beta$-diversity resulting from gamma diversity (total ant species in succession stages) minus alpha diversity (species richness per plots) and the similarity between epigaeic and arboreal ants (\%) was calculated using the percentage of species sampled in two strata in each plot.

We verified the response of estimated ant species richness, percentage of similarity between epigaeic and arboreal ants and $\beta$-diversity to successional stages and to seasons through general linear models (GLMs). All levels (stages) were compared in a contrast analysis for the aggregation levels and comparing the changes in deviations (Crawley, 2013). Analyses were followed by residual analyses to assess the adequacy of the models and error distribution (Crawley, 2013). All analyses were performed in R platform ( $\mathrm{R}$ Development Core Team, 2014).

The responses of estimated ant species richness to variables measured in the arboreal (richness of tree species, 
basal circumference and canopy cover), epigaeic (richness of tree species, leaf-litter dry weight and canopy cover) and hypogaeic (richness of tree species, moisture, density and porosity of the soil) strata were verified using GLMs. Succession stage was added to the models as a covariate. Estimates of resources and conditions were used as explanatory variables, and the estimated ant species richness in each stratum was the response variable in each model. Non-significant explanatory variables were withdrawn from the complete models, which were subjected to residual analyses to assess the adequacy of the model and the distribution of errors used (Crawley, 2013). All tests were performed using R software (R Development Core Team, 2014).

To test the relationship between the environmental variables with successional stages we used GLMs, using normal errors when the response variable was an average and poisson errors when the response variable was count data. The analyses were performed using R (R Development Core Team, 2014).

Using permutation multivariate analysis of variance (PERMANOVA, Anderson, 2001) we tested the influence of successional stages, stratum and seasons and their interaction on ant assemblage composition, using the Jaccard dissimilarity measure and 999 permutations. PERMANOVA is a permutation anova, which was developed to test the simultaneous response of one or more variables to one or more factors in analyses of variance (Anova). A permutation multivariate analysis of dispersion (PERMDISP) was then run on this Jaccard dissimilarity matrix to test the differences in the homogeneity of ant assemblages across successional stages, stratum and seasons (Anderson, 2001; 2006). PERMDISP compares the distances from observations to their group centroid (analogous to a measure of variance) and thus allowed us to compare the heterogeneity of ant assemblage between the factors. The PERMANOVA used the 'adonis' procedure and the PERMDISP used the 'betadisper' procedure in the vegan package in $\mathrm{R}$.

\section{Results}

Ant fauna

We collected 95 ant species from 26 genera. The subfamily with the highest diversity was the Myrmicinae (55 species), followed by Formicinae (21 species), Pseudomyrmecinae (six species), Dolichoderinae (five species), Dorylinae (three species), Ponerinae (two species each). Amblyoponinae, Ectatomminae and Heteroponerinae were each only represented by a single species. Only four species of ants were found in all three successional stages and in both seasons: Camponotus blandus, Cyphomyrmex transversus, Pheidole sp. 01 and Pheidole sp. 07. The species Camponotus substitutus was found in all three stages of succession but only in the wet season, and Ectatomma edentatum, Camponotus pr. lespesii, Cephalotes grandinosus, Solenopsis sp. 01, Solenopsis sp. 11 and Solenopsis saevissima were found in all three stages but only in the dry season (Appendix S2).

In the species accumulation curve we observed a tendency to an asymptote, indicating that the sampling effort was sufficient (Appendix S3). These data suggest that the number of ant species sampled is close to the total number of species in dry and wet season.

\section{Ant species richness}

The estimated ant species richness, accumulated in all strata was significantly higher in the intermediate and late stages of succession ( $F=3.90 ; p=0.049$; Fig 2A, Appendix $\mathrm{S} 1)$. Nevertheless, arboreal and epigaeic ant richness did not change with the progress of ecological succession, but hypogaeic ant species richness was higher in the intermediate and late stages of succession $(\mathrm{F}=6.31 ; \mathrm{p}=0.013$; Fig $2 \mathrm{~B})$. Similarity between epigaeic and arboreal ants change along the succession. A higher similarity between the two strata was found in the initial stage and decreased significantly in the intermediate and late stages $(\mathrm{F}=13.47 ; \mathrm{p}=0.0004$; Fig $2 \mathrm{C}$ ). With respect to seasonal effects, ant species richness was higher in the dry season (25 ant species) than in the wet season $(17,8$ ant species) $(F=13.06 ; p=0.001)$. $\beta$-diversity was significantly higher in the intermediate and late stages of succession $($ Deviance $=23.661 ; \mathrm{p}<0.001 ;$ Fig 2D), which may be a response to floristic differentiation along succession process (Solar et al., 2015).

Arboreal and epigaeic ant species richness were not correlated to any of the variables used as surrogates of resources and conditions $(p>0.05)$. Hypogaeic ant species richness increased significantly with soil porosity $(\mathrm{F}=8.20 ; \mathrm{p}$ $=0.013 ;$ Fig $3 \mathrm{~A})$, soil moisture $(\mathrm{F}=6.48 ; \mathrm{p}=0.024 ;$ Fig $3 \mathrm{~B})$ and plant species richness $(\mathrm{F}=6.71 ; \mathrm{p}=0.022 ; \mathrm{Fig} 3 \mathrm{C})$. Soil density was negatively correlated with porosity $(r=95.1 \%)$.

Successional stage affected only four surrogates of resources and conditions: soil average porosity $(\mathrm{F}=20.54 ; \mathrm{p}$ $=0.0001)$, leaf-litter average dry weight $(\mathrm{F}=8.68 ; \mathrm{p}=0.004)$ and plant species richness $(\mathrm{p}<0.0001)$ had an increasing trend along succession process while the soil average moisture $(\mathrm{F}=$ 5.48; $\mathrm{p}=0.035$ ) had a decreasing trend.

\section{Changes in ant assemblage composition}

Ant assemblage composition changes among successional stages (Permanova, $\mathrm{p}<0.001$, Table 1) and stratum (Permanova, $p<0.001$, Table 1), that is, the position of centroids differed. Moreover, there was not a significant interaction between factors $(p>0.05)$. When we consider the seasonal effect, ant composition differed significantly between seasons (Permanova, $\mathrm{p}<0.001$, Table 1). Permdisp revealed significantly greater average distance from centroids in early (0.35) than intermediate and late successional stages ( 0.19 and 0.12) $($ F-value $=28.11, \mathrm{p}<0.0001$, Table 1). Average distance in arboreal $(0.43)$ is also greater than in epigaeic 

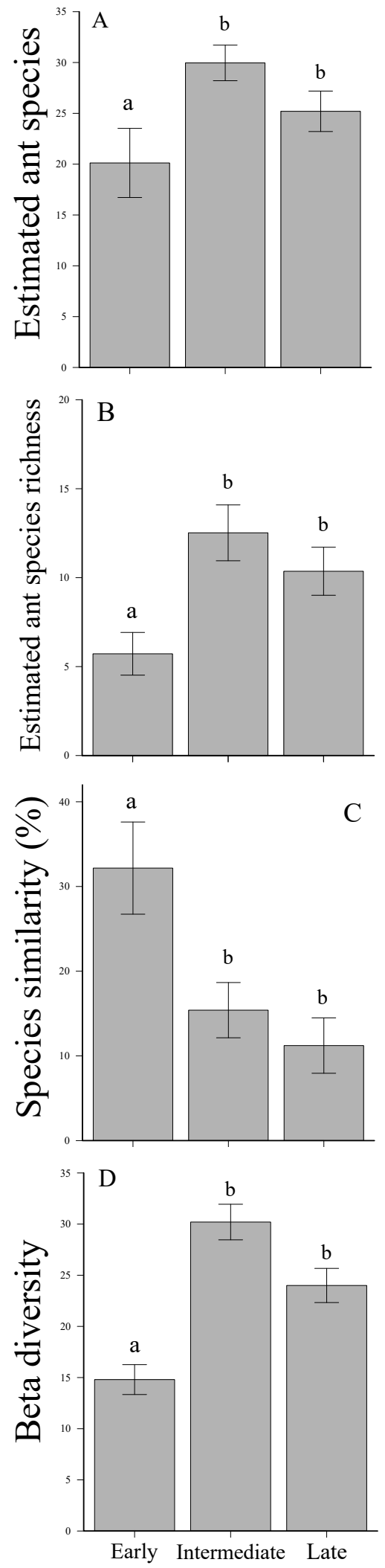

\section{Successional stages}

Fig 2. Estimated total ant species richness (mean $\pm \mathrm{SE})(\mathrm{A})$, estimated hypogaeic ant species richness (mean $\pm \mathrm{SE})(\mathrm{B})$, similarity between epigaeic and arboreal species of ants $(\mathrm{C})$, and beta diversity in a Tropical Dry Forest from different the successional stages (D). Different letters represent statistically significant differences between successional stages as determined by contrast analysis $(P<0.05)$.
$(0.32)$ and hypogaeic stratum $(0.36)$ from centroid (F-value $=$ 9.27, $\mathrm{p}<0.001$, Table 1). Moreover, ant composition in dry season is more distant from centroids $(0.34)$ than wet season $(0.12)($ F-value $=65.24, \mathrm{p}<0.0001$, Table 1$)$.

Table 1. Pair-wise permutation tests of differences in position and dispersion of ant species assemblages sampled in secondary Tropical Dry Forest located in Minas Gerais, Brazil.

\begin{tabular}{llll}
\hline & Factors & Permanova & Permdisp \\
& & $r^{2}$ & $F$-value \\
\hline \multirow{2}{*}{ Ant assemblages } & Successional stages & $\mathbf{0 . 0 8 * *}$ & $\mathbf{2 8 . 1 1 * * *}$ \\
& Stratum & $\mathbf{0 . 4 2 * *}$ & $\mathbf{9 . 2 7 * *}$ \\
& Stages*Stratum & $\mathbf{0 . 5 0}$ & \\
& Seasons & $\mathbf{0 . 1 1 * *}$ & $\mathbf{6 5 . 2 4 * * *}$ \\
\hline
\end{tabular}

Significant differences are in bold. $* *<0.001, * * *<0.0001$.

\section{Discussion}

Biological mechanisms driving succession

The variation on species richness found in the ant assemblages in the studied TDF is consistent with the model of an assemblage controlled by dominance (see Dauber \& Wolters, 2004; 2005). This model predicts that ant diversity will be lower in the early stages of succession and that the area will be colonized by generalist species that are common in open and modified environments, such as Acromyrmex landolti, Brachymyrmex patagonicus, Cyphomyrmex gr. rimosus sp. 01, Pheidole sp. 03 and Solenopsis spp. The early stage revealed a differentiated species composition, and most species that were present can tolerate extreme conditions, such as low humidity and high temperatures caused by high solar irradiation from the discontinuous canopy of the forest (Neves et al., 2013). Throughout the succession process, other species colonized the plots, which caused an increase in the diversity of ants in the advanced stages of succession. The following mechanisms might explain the response of ant assemblages to ecological succession: (1) competition-colonization balance, in which competing species exclude species that are competitively inferior when both occupy the same area; and (2) the availability of adequate environmental conditions and resources to colonizing species.

The first mechanism is centered on the processes of interaction among species, and assumes that interspecific competition is a limiting factor for the species richness of ant assemblages. Although competitive interactions are usually considered important in the structure of ant assemblages (Baccaro et al., 2011), some authors have reservations about the widespread importance of competition as a structuring force in the ant assemblages in the Neotropical region (e.g. Ribas \& Schoereder, 2002).

The second mechanism is grounded in changes in physical structure of the environment that occur during the successional process. In tropical forests, plant succession 


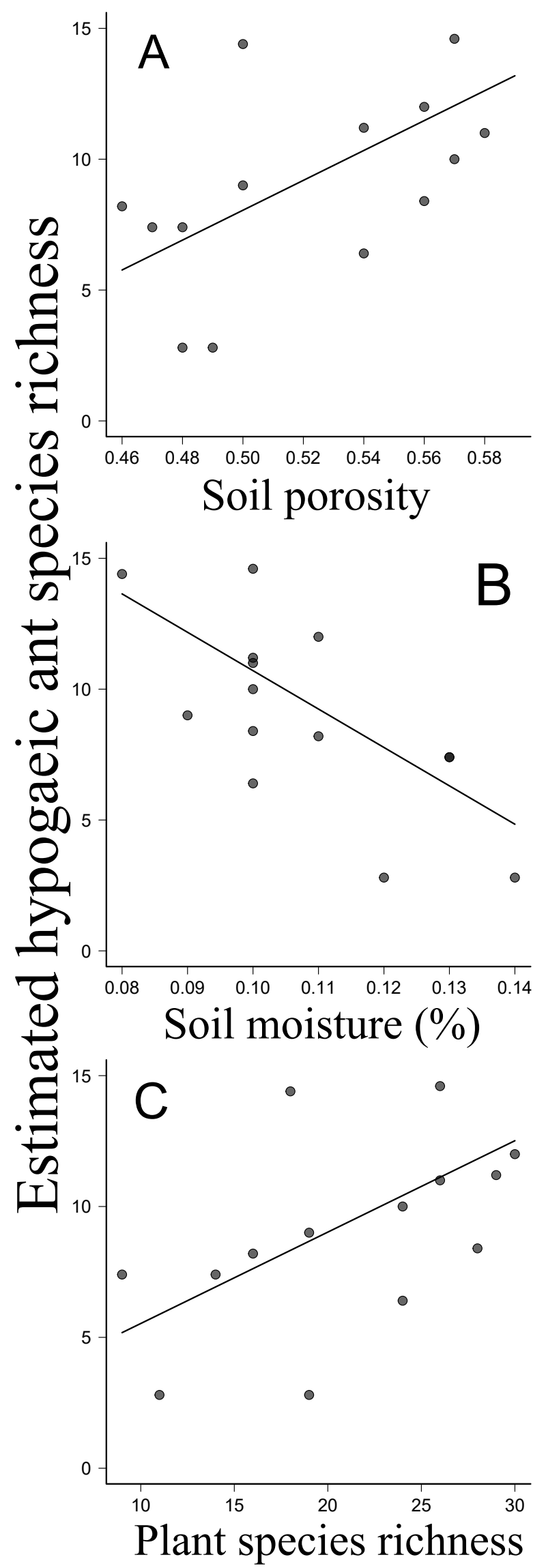

Fig 3. Responses of the estimated hypogaeic ant species richness to soil porosity (A), soil moisture (B) and tree species richness (C) in a Tropical Dry Forest from different successional stages in Parque Estadual da Mata Seca, Minas Gerais, Brazil $(P<0.05)$. after a disturbance is often characterized by an increase in the structural complexity of the habitat, along with an increase in the quantity and diversity of resources (Kalacska et al., 2004; Madeira et al., 2009), both considered important factors for structuring ant assemblages (Ribas et al., 2003; Ribas \& Schoereder, 2007; Klimes et al., 2012). With an increase of resources and changes of conditions along successional stages, a higher number of ant species can coexist in the same area because they occupy different spatial niches. Solar et al. (2015) found higher $\beta$-diversity within all disturbance classes (logged, burnt, pasture, agriculture) in tropical forests, indicating less evidence for biotic homogenization within forests. Accordingly, secondary forests maintained a high level of $\beta$-diversity among sites despite the initial disturbance (e.g. conversion to pasture or agriculture) removing the original biological assemblages, which reflects the importance of variation introduced by different successional pathways. Then, the higher ant richness in the advanced successional stages may respond to an increase in environmental heterogeneity, which holds a higher $\beta$-diversity of ants in these stages. Much of this variation in diversity occurred in the subterranean ant fauna, because in terms of richness only the ants of the hypogaeic stratum responded to ecological succession in the studied TDF.

During natural regeneration, soil goes through physical changes due to the establishment of different plant species in the disturbed area. The areas in the early successional stage are characterized by bush vegetation and highly compacted soil because they were previously used as pasture until 2000. In the intermediate and late stages, there is a higher diversity of plants, and the soil is more porous. The hypogaeic stratum presents change in the ant fauna (Schmidt \& Solar, 2010) that are closely linked to processes occurring in the vegetation, which could also contribute to the movement of water and soil as well as nutrient cycling (Sousa-Souto et al., 2007). Thus, the changes in soil following disturbance exert pressure on the ant assemblage in this stratum, which results in a decrease in diversity. Schmidt et al. (2013) found a similar relationship between hypogaeic species richness and soil density in Atlantic Rainforest fragments. In the studied TDF, the colonization of new ant species parallels the physical structure and condition changes of the soil, as well as the increase of plant diversity along the successional process. Moreover, these environmental changes reflect not only in the richness, but also in the composition of the hypogaeic ant assemblage, which was sensitive to changes that occur in its stratum.

The importance of mechanisms determining the richness of ants differs between strata. Unlike hypogaeic ants, arboreal and epigaeic ant assemblages are consistent with the model of an assemblage controlled by foundation. This model predicts that diversity would not vary throughout successional process. Inhibition, facilitation and tolerance are the three mechanisms involved in the diversity regulation in this assemblage model (Connell \& Slatyer, 1977). The dynamics of each mechanism is based on different species interactions. These mechanisms 
are more commonly observed in plant assemblages that are undergoing succession (Connell \& Slatyer, 1977). For arboreal and epigaeic ant assemblages of our study, we hypothesize that habitat conditions influence more strongly ant species richness than the mechanisms that involve intraspecific interactions (inhibition, facilitation or tolerance).

We found some evidence to our hypothesis that habitat condition is an important regulator of ant species richness in arboreal and epigaeic strata. Our results point to a pronounced vertical stratification of the ant assemblages, which presents a decrease in similarity among epigaeic and arboreal strata along succession process. Neves et al. (2010b) found the same results in the same study site. This vertical stratification occurs with the establishment of ant dominant species along succession. Crematogaster obscurata is found in dry forests and nests in the dead portions of live trees (Longino, 2003). Species of this genus, and other members of the Azteca and Camponotus genera, are usually very aggressive and dominate the resources that are exploited by their assemblages. Despite being dominant and found in dry habitats, $C$. obscurata was collected only in intermediate and late stages of succession, along with the Azteca species and Camponotus arboreus. Therefore, the occurrence of these species in advanced successional habitats may be due to the presence of specific resources for structuring large nests, such as trees that have larger $\mathrm{CBH}$, and not because some early ant species inhibit, tolerate or prepare the environment for the establishment of these ant species.

\section{Seasonal variation}

In the tropics, some insect populations are influenced by seasonal changes in temperature and moisture (Guedes et al., 2000), and ant assemblages are generally more diverse during the wet season (Torchote et al., 2010). Contrary to most studies in humid tropical forests, we found higher ant species richness during the dry season, demonstrating that such information is not adequate to the studies conducted on TDFs. This pattern of seasonal variation has been found in other TDFs. For example, assemblages of arboreal and terrestrial ants in a Mexican TDF (Gove et al., 2005) also have higher species richness in the dry season. However, Neves et al. (2010b) using baited pitfall traps, found no seasonal differences in the arboreal ants species richness in the same TDF investigated in the present study. The presence of baits could induce distinct foraging patterns and alter the natural feeding pattern because high-protein and high-calory resources are being offered. Furthermore, we believe that the presence of bait provided an even distribution of resources, which made the areas more equivalent in terms of resources. Thus, the results of our study show a natural increase in the ant species number foraging in the dry season during different successional stages.

The mechanism proposed by Lassau and Hochuli (2004) for the diversity of ants in less complex habitats might explain the higher ant species number collected in the TDF during the dry season. The foliar deciduousness of the trees could have simplified the physical environment by reducing the moisture and shade levels, which could have facilitated nest building and foraging by the ants, especially because most species are thermophilic (Holldobler \& Wilson, 1990). Moreover, as the availability of resources decreased in the dry season, the ants needed to increase their foraging area to find food, thereby increasing the chances that they would fall into the traps. During the wet season, the opposite process would occur, explaining the variation in species number and composition change between seasons.

\section{Secondary TDFs conservation}

Although the history of TDFs is marked by human exploitation, the future of this unique and diverse ecosystem depends on conservation, management and restoration. Our results showed that environments with a simple physical structure (e.g., degraded forests) did not support species from the forest. A considerable fraction of species only appeared in the advanced stages of succession, reinforcing the importance of secondary habitats in maintaining the ecosystem biodiversity (Gomes et al., 2014).

We hypothesize that the restoration of the ant diversity in TDFs is faster than in rainforests. Bihn et al. (2008) found that even after 35-50 years of regeneration in an Atlantic forest, the ant assemblage did not show the species richness and composition expected for a mature forest. Based on the pattern of succession in TDF, it is likely that 25 years of regeneration in this forest would be sufficient to restore the ant composition and richness, as also showed in the estimates made by Neves et al. (2010b). Tropical rain forests usually have a high level of alpha diversity (Lopez \& ZambranaTorrelio, 2006), and when interactions are disrupted by habitat disturbance, species recolonization and the establishment of inter and intraspecific interactions can take longer than the same processes in TDFs, which explains the difference in the resilience times for these different areas.

\section{Acknowledgments}

The authors would like to thank C. F. Sperber, O. DeSouza, R. C. Solar and anonymous referees for reviewing the manuscript as well as A. Queiroz and D. de Paula for their help conducting fieldwork. We also thank R. S. M. Feitosa and V. E. Sandoval-Gómez for their assistance with identifying the ants. We are grateful to IEF for allowing this work to be performed at the PEMS and for the logistical support. This work received financial assistance from FAPEMIG and the Inter-American Institute for Global Change Research CRN II \# 021, which is funded by the U.S. National Science Foundation (GEO 0452325). Finally, we would like to thank CAPES and CNPq for the authors' grants. 


\section{References}

Anderson, M.J. (2001). A new method for non-parametric multivariate analysis of variance. Austral Ecology, 26: 32-46. doi: 10.1111/j.1442-9993.2001.01070.pp.x

Anderson, M.J. (2006). Distance-based tests for homogeneity of multivariate dispersions. Biometrics, 62: 245-53. doi: 10.1 111/j.1541-0420.2005.00440.x

Baccaro, F., De Souza, J., Franklin, E., Landeiro, V \& Magnusson, W. (2011). Limited effects of dominant ants on assemblage species richness in three Amazon forests. Ecological Entomology, 37: 1-12. doi: 10.1111/j.1365-2311. 2011.01326.x

Bihn, J., Verhaagh, M \& Brand, R. (2008). Ecological stoichiometry along a gradient of forest succession: bait preferences of litter ants. Biotropica, 40: 597-599. doi: 10.111 1/j.1744-7429.2008.00423.x

Bolton, B. (2016). An online catalog of the ants of the world. Available from http://antcat.org. (accessed 23 august 2016)

Colwell, R.K. (2006). EstimateS: Statistical Estimation of Species Richness and Shared Species from Samples. Version $8<$ purl.oclc.org/ estimates $>$.

Connell, J. \& Slatyer, R. (1977). Mechanisms of succession in natural communities and their role in community stability and organization. The American Naturalist, 111: 1119-1144. doi: $10.1086 / 283241$

Crawley, M.J. (2013). The R Book. 2 ${ }^{\text {nd }}$ Edition. Jonh Wiley, New York, USA, 1076p.

Cuevas-Reyes, P., Quesada, M. \& Oyama, K. (2006). Abundance and leaf damage caused by gall-inducing insects in a Mexican tropical dry forest. Biotropica, 38: 107-115. doi: 10.1111/j.1744-7429.2006.00115.x

Dauber, J. \& Wolters, V. (2004). Edge effects on ant community structure and species richness in an agricultural landscape. Biodiversity and Conservation, 13: 901-915. doi: 10.1023/B:BIOC.0000014460.65462.2b

Dauber, J. \& Wolters, V. (2005). Colonization of temperate grassland by ants. Basic and Applied Ecology, 6: 83-91. doi: 10.1016/j.baae.2004.09.011

Frazer, G., Canham, C. \& Lertzman, K. (1999). Gap Light Analyzer (GLA): imaging software to extract canopy structure and gap light transmission indices from true-color fisheye photographs, user manual and program documentation. Simon Fraser Institute of Ecosystem Studies, Millbrook, New York, USA, 36p.

Godfray, H. \& Lawton, J. (2001). Scale and species numbers. Trends in Ecology and Evolution, 16: 400-404. doi: 10.1016/ S0169-5347(01)02150-4

Gomes, E.C.F., Ribeiro, G.T., Souza, T.M.S. \& Sousa-Souto, L. (2014). Ant assemblages (Hymenoptera: Formicidae) in three different stages of forest regeneration in a fragment of
Atlantic Forest in Sergipe, Brazil. Sociobiology, 61: 250-257. doi: 10.13102/sociobiology.v61i3.250-257

Gotelli, N., Ellison, A., Dunn, R. \& Sanders, N. (2011). Counting ants (Hymenoptera: Formicidae): biodiversity sampling and statistical analysis for myrmecologists. Myrmecological News, 15: 13-19.

Gotelli, N. \& Colwell, R.K. (2011). Estimating species richness. In A.N. Magurran \& B.J. McGill (Eds.), Biological diversity: frontiers in measurement and assessment (pp. 39-54). Oxford: Oxford University Press.

Gove, A., Majer, J. \& Rico-Gray, V. (2005). Methods for conservation outside of formal reserve systems: the case of ants in the seasonally dry tropics of Veracruz, Mexico. Biological Conservation, 126: 328-338. doi: 10.1016/j.biocon.2005.06.008

Guedes, R., Zanuncio, T., Zanuncio, J. \& Medeiros, A. (2000). Species richness and fluctuation of defoliator Lepidoptera populations in Brazilian plantations of Eucalyptus grandis as affected by plant age and weather factors. Forest Ecology and Management, 137: 179-184. doi: 10.1016/S0378-1127(99)00326-6

Holldobler, B. \& Wilson, E. (1990). The ants. Cambridge: Harvard University Press, 732p.

Jacquemin, J., Roisin, Y. \& Leponce, M. (2016). Spatiotemporal variation in ant (Hymenoptera: Formicidae) communities in leaf-litter and soil layers in a Premontane Tropical Forest. Myrmecological News, 22: 129-139.

Kalacska, M., Sanchez-Azofeifa, G.A., Calvo-Alvarado, J.C., Quesada, M., Rivard, B. \& Janzen, D.H. (2004). Species composition, similarity and diversity in three successional stages of a seasonally dry tropical forest. Forest Ecology and Management, 200: 227-247. doi: 10.1016/j.foreco.2004.07.001

Klimes, P., Idigel, C., Rimandai, M., Fayle, T.M., Janda, M., Weiblen, G.D. \& Novotny, V. (2012). Why are there more arboreal ant species in primary than secondary forests? Journal of Animal Ecology, 81: 1103-1112. doi: 10.1111/j.13652656.2012.02002.x

Lambi, E. (1996). Change detection at multiple temporal scales: seasonal and annual variations in landscape variables. Photogrammetric Engineering and Remote Sensing, 62: 931-938.

Lassau, S. \& Hochuli, D. (2004). Effects of habitat complexity on ant assemblages. Ecography, 27: 157-164. doi: 10.1111/j. 0906-7590.2004.03675.x

Longino, J. (2003). The Crematogaster (Hymenoptera, Formicidae, Myrmicinae) of Costa Rica. Zootaxa, 151: 1-150. doi: 10.11646/zootaxa.151.1.1

Lopez, R. \& Zambrana-Torrelio, C. (2006). Representation of andean dry ecoregions in the protected areas of Bolivia: the situation in relation to the new phytogeographical findings. Biodiversity and Conservation, 15: 2163-2175. doi: 10.1007/ s10531-004-6898-4 
Madeira, B., Espirito-Santo, M., Neto, S., Nunes, Y., Azofeifa, G., Fernandes, G. \& Quesada, M. (2009). Changes in tree and liana communities along a successional gradient in a tropical dry forest in south-eastern Brazil. Plant Ecology, 201: 291304. doi: 10.1007/s11258-009-9580-9

Muscardi, D., Almeida, S., Schoereder, J., Marques, T., Sarcinelli, T. \& Correa, A. (2008). Response of litter ants (Hymenoptera: Formicidae) to habitat heterogeneity and local resource availability in native and exotic forests. Sociobiology, 52: 655-665.

Neves, F., Braga, R., Espírito-Santo, M., Delabie, J., Fernandes, G. \& Sánchez-Azofeifa, G. (2010a). Seasonal and successional changes in a community of dung bettles (Coleoptera: Scarabaeinae) in a Brazilian tropical dry forest. Brazilian Journal for Nature Conservation, 8: 160-164. doi: 10.4322/natcon.00802009

Neves, F.S., Braga, R.F., Espirito-Santo, M.M., Delabie, J.H.C., Wilson, F.G. \& Sanchez-Azofeifa, G.A. (2010b). Diversity of arboreal ants in a brazilian tropical dry forest: effects of seasonality and successional stage. Sociobiology, 56: 177-194.

Neves, F.S., Sperber, C.F., Campos, R.I., Soares, J.P. \& Ribeiro, S.P. (2013). Contrasting effects of sampling scale on insect herbivores distribution in response to canopy structure. Revista de Biologia Tropical, 61:125-137.

Neves, F.S., Silva, J.O., Espírito-Santo, M.M. \& Fernandes, G.W. (2014). Insect herbivores and leaf damage along successional and vertical gradients in a tropical dry forest. Biotropica, 46: 14-24. doi: 10.1111/btp.12068

Pezzini, F.F., Ranieri, B.D., Brandão, D.O., Fernandes, G.W., Quesada, M., Espírito- Santo, M.M. \& Jacobi, C.M. (2014). Changes in tree phenology along natural regeneration in a seasonally dry tropical forest. Plant Biosystems, 148: 965-974. doi: 10.1080/11263504.2013.877530.

R Development Core Team (2014) R: A language and environment for statistical computing. $\mathrm{R}$ foundation for statistical computing, Vienna. ISBN 3-900051-07-0, [Cited 15 January 2015.] Available from: http://www.R-project. org

Ribas, C. \& Schoereder, J. (2002). Are all ant mosaics caused by competition? Oecologia, 131: 606-611. doi: 10.1007/s00442002-0912-x

Ribas, C., Schoereder, J., Pic, M. \& Soares, S. (2003). Tree heterogeneity, resource availability, and larger scale processes regulating arboreal ant species richness. Austral Ecology, 28: 305-314. doi: 10.1046/j.1442-9993.2003.01290.x

Ribas, C. \& Schoereder, J. (2007). Ant communities, environmental. characteristics and their implications for conservation in the brazilian Pantanal. Biodiversity and Conservation, 16: 1511-1520. doi: 10.1007/s10531-006-9041-x

Sagar, R. \& Verma, P. (2010). Effects of soil physical characteristics and biotic interferences on the herbaceous community composition and species diversity on the campus of Banaras Hindu University, India. Environmentalist, 30: 289-298. doi: 10.1007/s10669-010-9276-7

Sanchez-Azofeifa, G.A., Quesada, M., Rodriguez, J.P., Nassar, J.M., Stoner, K.E., Castillo, A., Garvin, T., Zent, E.L., Calvo-Alvarado, J.C., Kalacska, M.E.R., Fajardo, L., Gamon, J.A. \& Cuevas-Reyes, P. (2005). Research priorities for neotropical dry forests. Biotropica, 37: 477-485. doi: 10.1046/ j.0950-091x.2001.00153.x-i1

Schmidt, F.A. \& Solar, R.R.C. (2010). Hypogaeic pitfall traps: methodological advances and remarks to improve the sampling of a hidden ant fauna. Insectes Sociaux, 57: 261266. doi: 10.1007/s00040-010-0078-1

Schmidt, F.A., Ribas, C.R. \& Schoereder, J.H. (2013). How predictable is the response of ant assemblages to natural forest recovery? implications for their use as bioindicators. Ecological Indicators, 24: 158-166. doi: 10.1016/j.ecolind.2012.05.031

Siemann, E., Haarstad, J. \& Tilman, D. (1999). Dynamics of plant and arthropod diversity during old field succession. Ecography, 22: 406-414. doi: 10.1111/j.1600-0587.1999.tb00577.x

Silva, E.M., Medina, A.M., Nascimento, I.C., Lopes, P.P., Carvalho, K.S. \& Santos, G.M.M. (2014). Does ant community richness and composition respond to phytophysiognomical complexity and seasonality in xeric environments? Sociobiology, 61: 155-163. doi: 10.13102/ sociobiology.v61i2.155-163

Solar, R.R.C., Barlow, J., Ferreira, J., Berenguer, E., Lees, A.C., Thomson, J.R., Louzada, J., Maues, M., Moura, N.G., Oliveira, V.H.F., Chaul, J.C.M., Schoereder, J.H., Vieira, I.C.G., Nally, R.M. \& Gardner, T.A. (2015). How pervasive is biotic homogenization in human-modified tropical forest landscapes? Ecology Letters, 18: 1108-1118. doi: 10.1111/ ele.12494.

Sousa-Souto, L., Schoereder, J. \& Schaefer, C. (2007). Leafcutting ants, seasonal burning and nutrient distribution in Cerrado vegetation. Austral Ecology, 32: 758-765. doi: 10.11 11/j.1442-9993.2007.01756.x

Sousa-Souto, L., Figueiredo, P.M.G., Ambrogi, B.G., Oliveira, A.C.F., Ribeiro, G.T. \& Neves, F.S. (2016). Composition and richness of arboreal ants in fragments of brazilian Caatinga: effects of secondary succession. Sociobiology, 63: 762-769. doi: 10.13102/sociobiology.v63i2.909

Torchote, P., Sitthicharoenchai, D. \& Chaisuekul, C. (2010). Ant species diversity and community composition in three different habitats: mixed deciduous forest, teak plantation and fruit orchard. Tropical Natural History, 10: 37-51.

Underwood, E. \& Fisher, B. (2006). The role of ants in conservation monitoring: If, when, and how. Biological Conservation, 132: 166-182. doi: 10.1016/j.biocon.2006.03.022 
Vargas, R., Allen, M. \& Allen, E. (2008). Biomass and carbon accumulation in a fire chronosequence of a seasonally dry tropical forest. Global Change Biology, 14: 109-124. doi: 10.1111/j.1365-2486.2007.01462.x
Yu, D., Wilson, H. \& Pierce, N. (2001). An empirical model of species coexistence in a spatially structured environment. Ecology, 82: 1761-1771. doi: 10.2307/2679816 
Appendix S1. Observed and estimated ant species richness* collected in a Tropical Dry Forest fragment from different successional stages in Parque Estadual da Mata Seca, Minas Gerais, Brazil.

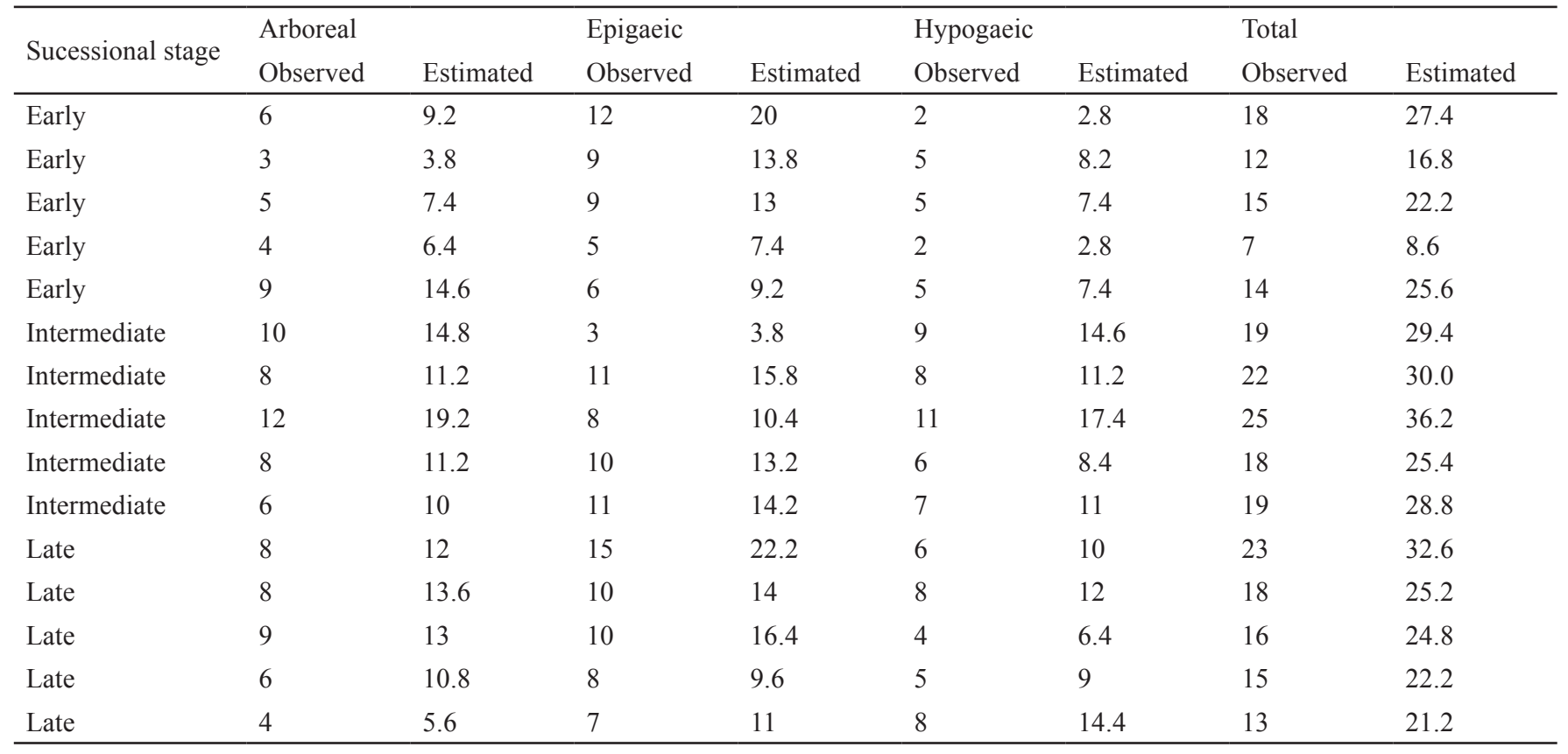

* All analyses were performed both with observed and estimated richness and results were similar.

Appendix S2. Ant species collected in a Tropical Dry Forest fragment from different successional stages in Parque Estadual da Mata Seca during the dry and rainy seasons. $\mathrm{A}=$ arboreal stratum, $\mathrm{E}=$ epigaeic stratum and $\mathrm{H}=$ hypogaeic stratum.

\begin{tabular}{|c|c|c|c|c|c|c|}
\hline \multirow{3}{*}{ Taxa } & \multicolumn{6}{|c|}{ Stages / Seasons } \\
\hline & \multicolumn{2}{|c|}{ Initial } & \multicolumn{2}{|c|}{ Intermediate } & \multicolumn{2}{|l|}{ Late } \\
\hline & Dry & Rainy & Dry & Rainy & Dry & Rainy \\
\hline \multicolumn{7}{|l|}{ Amblyoponinae } \\
\hline Prionopelta punctulata Mayr, 1866 & & & & $\mathrm{H}$ & $\mathrm{H}$ & $\mathrm{H}$ \\
\hline \multicolumn{7}{|l|}{ Dorylinae } \\
\hline Acanthostichus serratulus (Smith, 1858) & & $\mathrm{H}$ & & $\mathrm{H}$ & & \\
\hline Cheliomyrmex morosus (Smith, 1859) & & & & $\mathrm{H}$ & & \\
\hline Labidus coecus (Latreille, 1802) & & & & $\mathrm{H}$ & $\mathrm{H}$ & \\
\hline \multicolumn{7}{|l|}{ Dolichoderinae } \\
\hline Azteca sp. 01 & & & & & A & \\
\hline Azteca (gr. alfari) sp. 02 & & & & & & A \\
\hline Dorymyrmex sp. 01 & & & $\mathrm{E}$ & & & \\
\hline Forelius brasiliensis Forel, 1908 & & $\mathrm{E}$ & $\mathrm{E}$ & & & $\mathrm{E}$ \\
\hline Tapinoma melanocephalum (Fabricius, 1793) & A & & & & $\mathrm{H}$ & \\
\hline \multicolumn{7}{|l|}{ Ectatomminae } \\
\hline Ectatomma edentatum Roger, 1863 & $\mathrm{E}$ & & $\mathrm{AEH}$ & & $\mathrm{E}$ & \\
\hline \multicolumn{7}{|l|}{ Formicinae } \\
\hline Brachymyrmex sp. 01 & & & & & $\mathrm{H}$ & \\
\hline Brachymyrmex sp. 02 & & & & & $\mathrm{E}$ & \\
\hline Brachymyrmex coactus (Mayr, 1887) & & & & EH & & $\mathrm{H}$ \\
\hline Brachymyrmex pr. coactus & & & $\mathrm{H}$ & & $\mathrm{E}$ & \\
\hline Brachymyrmex pr. longicornis & & & & $\mathrm{H}$ & $\mathrm{H}$ & \\
\hline Brachymyrmex patagonicus Mayr, 1868 & $\mathrm{AEH}$ & & & & & \\
\hline Camponotus sp. 01 & & & A & & & \\
\hline Camponotus sp. 02 & & & $\mathrm{AE}$ & & $\mathrm{AE}$ & \\
\hline
\end{tabular}


Appendix S2. Ant species collected in a Tropical Dry Forest fragment from different successional stages in Parque Estadual da Mata Seca during the dry and rainy seasons. $\mathrm{A}=$ arboreal stratum, $\mathrm{E}=$ epigaeic stratum and $\mathrm{H}=$ hypogaeic stratum. (Cont.)

\begin{tabular}{|c|c|c|c|c|c|c|}
\hline \multirow{3}{*}{ Taxa } & \multicolumn{6}{|c|}{ Stages / Seasons } \\
\hline & \multicolumn{2}{|l|}{ Initial } & \multicolumn{2}{|c|}{ Intermediate } & \multicolumn{2}{|l|}{ Late } \\
\hline & Dry & Rainy & Dry & Rainy & Dry & Rainy \\
\hline \multicolumn{7}{|l|}{ Formicinae } \\
\hline Camponotus arboreus (Smith, 1858) & & & $\mathrm{AE}$ & $\mathrm{AE}$ & A & $\mathrm{AE}$ \\
\hline Camponotus atriceps (Smith, 1858) & & & $\mathrm{AE}$ & & $\mathrm{AE}$ & \\
\hline Camponotus blandus Forel, 1901 & $\mathrm{AE}$ & $\mathrm{AE}$ & $\mathrm{AE}$ & $\mathrm{AE}$ & $\mathrm{E}$ & $\mathrm{E}$ \\
\hline Camponotus cingulatus Mayr, 1862 & & & & $\mathrm{AE}$ & & $\mathrm{AE}$ \\
\hline Camponotus crassus Mayr, 1862 & A & & $\mathrm{AE}$ & $\mathrm{AE}$ & & \\
\hline Camponotus germaini Emery, 1903 & & & & $\mathrm{AEH}$ & & $\mathrm{E}$ \\
\hline Camponotus pr. lespesii & $\mathrm{AE}$ & & $\mathrm{AE}$ & & $\mathrm{AEH}$ & \\
\hline Camponotus melanoticus Emery, 1894 & & $\mathrm{E}$ & & & & \\
\hline Camponotus renggeri Emery, 1894 & $\mathrm{AE}$ & $\mathrm{AE}$ & & & A & \\
\hline Camponotus substitutus Emery, 1894 & & $\mathrm{AEH}$ & & $\mathrm{AE}$ & & $\mathrm{AE}$ \\
\hline Camponotus pr. westermanni & & & & & A & \\
\hline Camponotus vittatus Forel, 1904 & & & $\mathrm{AE}$ & A & $\mathrm{AE}$ & $\mathrm{A}$ \\
\hline Nylanderia pr. guatemalensis & & & & & & $\mathrm{H}$ \\
\hline \multicolumn{7}{|l|}{ Heteroponerinae } \\
\hline Acanthoponera mucronata (Roger, 1860) & & & & & & A \\
\hline \multicolumn{7}{|l|}{ Myrmicinae } \\
\hline Acromyrmex landolti (Forel, 1885) & $\mathrm{E}$ & $\mathrm{E}$ & & & & \\
\hline Acromyrmex octospinosus (Reich, 1793) & $\mathrm{E}$ & & A & & & \\
\hline Acromyrmex rugosus (Smith, 1858) & & $\mathrm{EH}$ & & $\mathrm{E}$ & & \\
\hline Atta sexdens Forel, 1908 & & & & $\mathrm{E}$ & & \\
\hline Cephalotes atratus (Linnaeus,1758) & & & & A & A & A \\
\hline Cephalotes betoi De Andrade, 1999 & & & A & & & \\
\hline Cephalotes christopherseni (Forel, 1912) & $\mathrm{A}$ & & & & & \\
\hline Cephalotes grandinosus (Smith, 1860) & A & & $\mathrm{AE}$ & & $\mathrm{AEH}$ & \\
\hline Cephalotes minutus (Fabricius, 1804) & A & & & & & \\
\hline Cephalotes pavonii Latreille, 1809 & & A & & & & $\mathrm{E}$ \\
\hline Cephalotes pusillus (Klug, 1824) & A & A & & & $\mathrm{AE}$ & A \\
\hline Crematogaster abstinens Forel, 1899 & $\mathrm{E}$ & & & & & \\
\hline Crematogaster ampla Forel, 1912 & & & $\mathrm{AE}$ & A & & $\mathrm{A}$ \\
\hline Crematogaster pr. bruchi & $\mathrm{E}$ & & $\mathrm{E}$ & & & \\
\hline Crematogaster evallans (Forel, 1907) & & A & & & & \\
\hline Crematogaster obscurata (Emery, 1895c) & & & & & A & \\
\hline Crematogaster torosa Mayr, 1870 & & & & $\mathrm{AE}$ & & A \\
\hline Crematogaster pr. torosa & & & A & & A & \\
\hline Crematogaster victima Smith, 1858 & & & & & & A \\
\hline Cyphomyrmex gr. rimosus sp. 01 & $\mathrm{H}$ & & & & & \\
\hline Cyphomyrmex transversus Emery, 1884 & $\mathrm{E}$ & $\mathrm{H}$ & $\mathrm{H}$ & EH & $\mathrm{E}$ & $\mathrm{E}$ \\
\hline Pheidole sp. 01 & EH & $\mathrm{AEH}$ & $\mathrm{AE}$ & $\mathrm{AEH}$ & $\mathrm{AEH}$ & $\mathrm{AEH}$ \\
\hline Pheidole sp. 02 & & & $\mathrm{E}$ & $\mathrm{E}$ & $\mathrm{E}$ & EH \\
\hline Pheidole sp. 03 & $\mathrm{E}$ & & & & & \\
\hline Pheidole sp. 04 & $\mathrm{E}$ & $\mathrm{EH}$ & & & $\mathrm{E}$ & \\
\hline Pheidole sp. 05 & $\mathrm{EH}$ & $\mathrm{A}$ & & $\mathrm{H}$ & & $\mathrm{H}$ \\
\hline Pheidole sp. 06 & $\mathrm{AEH}$ & $\mathrm{EH}$ & & & & \\
\hline
\end{tabular}


Appendix S2. Ant species collected in a Tropical Dry Forest fragment from different successional stages in Parque Estadual da Mata Seca during the dry and rainy seasons. $\mathrm{A}=$ arboreal stratum, $\mathrm{E}=$ epigaeic stratum and $\mathrm{H}=$ hypogaeic stratum. (Cont.)

\begin{tabular}{|c|c|c|c|c|c|c|}
\hline \multirow{3}{*}{ Taxa } & \multicolumn{6}{|c|}{ Stages / Seasons } \\
\hline & \multicolumn{2}{|l|}{ Initial } & \multicolumn{2}{|c|}{ Intermediate } & \multicolumn{2}{|l|}{ Late } \\
\hline & Dry & Rainy & Dry & Rainy & Dry & Rainy \\
\hline \multicolumn{7}{|l|}{ Myrmicinae } \\
\hline Pheidole sp. 07 & $\mathrm{E}$ & $\mathrm{E}$ & $\mathrm{EH}$ & $\mathrm{EH}$ & $\mathrm{AEH}$ & $\mathrm{AEH}$ \\
\hline Pheidole sp. 08 & $\mathrm{AEH}$ & $\mathrm{E}$ & $\mathrm{EH}$ & $\mathrm{EH}$ & $\mathrm{AEH}$ & \\
\hline Pheidole sp. 09 & & & $\mathrm{H}$ & EH & & \\
\hline Pheidole sp. 10 & & & $\mathrm{H}$ & & & \\
\hline Pheidole sp. 11 & & & & $\mathrm{H}$ & & \\
\hline Pheidole sp. 12 & & & & $\mathrm{E}$ & & \\
\hline Rogeria blanda (Smith,1858) & & & $\mathrm{H}$ & & $\mathrm{H}$ & \\
\hline Solenopsis (gr. globularia) sp. 01 & $\mathrm{H}$ & & $\mathrm{H}$ & & $\mathrm{H}$ & \\
\hline Solenopsis sp. 02 & & & $\mathrm{H}$ & & $\mathrm{E}$ & \\
\hline Solenopsis sp. 03 & & & $\mathrm{H}$ & & $\mathrm{H}$ & \\
\hline Solenopsis sp. 04 & & & & & $\mathrm{H}$ & \\
\hline Solenopsis sp. 05 & & & $\mathrm{H}$ & & & \\
\hline Solenopsis (gp. globularia) sp.06 & & $\mathrm{H}$ & & & $\mathrm{EH}$ & \\
\hline Solenopsis sp. 07 & & $\mathrm{EH}$ & $\mathrm{H}$ & $\mathrm{H}$ & & $\mathrm{H}$ \\
\hline Solenopsis geminata (Fabricius, 1804) & $\mathrm{H}$ & $\mathrm{E}$ & & & & \\
\hline Solenopsis sp. 09 & EH & & & & $\mathrm{EH}$ & \\
\hline Solenopsis sp. 10 & & & $\mathrm{H}$ & & $\mathrm{H}$ & \\
\hline Solenopsis sp. 11 & $\mathrm{E}$ & & $\mathrm{AH}$ & & $\mathrm{H}$ & \\
\hline Solenopsis sp. 12 & & & $\mathrm{H}$ & & $\mathrm{H}$ & \\
\hline Solenopsis sp. 13 & & & $\mathrm{EH}$ & & & \\
\hline Solenopsis sp.14 & & & $\mathrm{H}$ & & & \\
\hline Solenopsis sp.15 & $\mathrm{H}$ & & & & $\mathrm{H}$ & \\
\hline Solenopsis sp.16 & & & & & & $\mathrm{H}$ \\
\hline Solenopsis sp.17 & & & & & & E-H \\
\hline Solenopsis saevissima (Smith, 1855) & $\mathrm{E}$ & & $\mathrm{AH}$ & & $\mathrm{H}$ & \\
\hline Strumigenys lilloana (Brown, 1950) & & & & & $\mathrm{H}$ & \\
\hline Wasmannia auropunctata (Roger, 1863) & & $\mathrm{E}$ & & & $\mathrm{EH}$ & $\mathrm{E}$ \\
\hline Wasmannia lutzi Forel, 1908 & A & & & & $\mathrm{E}$ & \\
\hline \multicolumn{7}{|l|}{ Ponerinae } \\
\hline Odontomachus bauri Emery, 1892 & & $\mathrm{E}$ & $\mathrm{E}$ & $\mathrm{H}$ & $\mathrm{E}$ & $\mathrm{E}$ \\
\hline Neoponera villosa (Fabricius, 1804) & & & $\mathrm{E}$ & & A & \\
\hline \multicolumn{7}{|l|}{ Pseudomyrmecinae } \\
\hline Pseudomyrmex flavidulus (Smith, 1858) & & A & & & & \\
\hline Pseudomyrmex gracilis (Fabricius, 1804) & $\mathrm{A}$ & & & A & & \\
\hline Pseudomyrmex (gr. pallidus) sp. 03 & A & & & & & \\
\hline Pseudomyrmex (gr. pallidus) sp. 04 & A & & & & & \\
\hline Pseudomyrmex schuppi (Forel, 1901) & & & A & A & & A \\
\hline Pseudomyrmex termitarius (Smith, 1855) & $\mathrm{AE}$ & $\mathrm{E}$ & $\mathrm{E}$ & & & $\mathrm{E}$ \\
\hline
\end{tabular}


Appendix S3. Sample-based species accumulation curve of the total number of ant species collected with arboreal, epigaeic and hypogaeic pitfall traps placed in Tropical Dry Forest fragments from different successional stages in Parque Estadual da Mata Seca, Minas Gerais, Brazil. Shaded area represents one standard deviation around mean values.

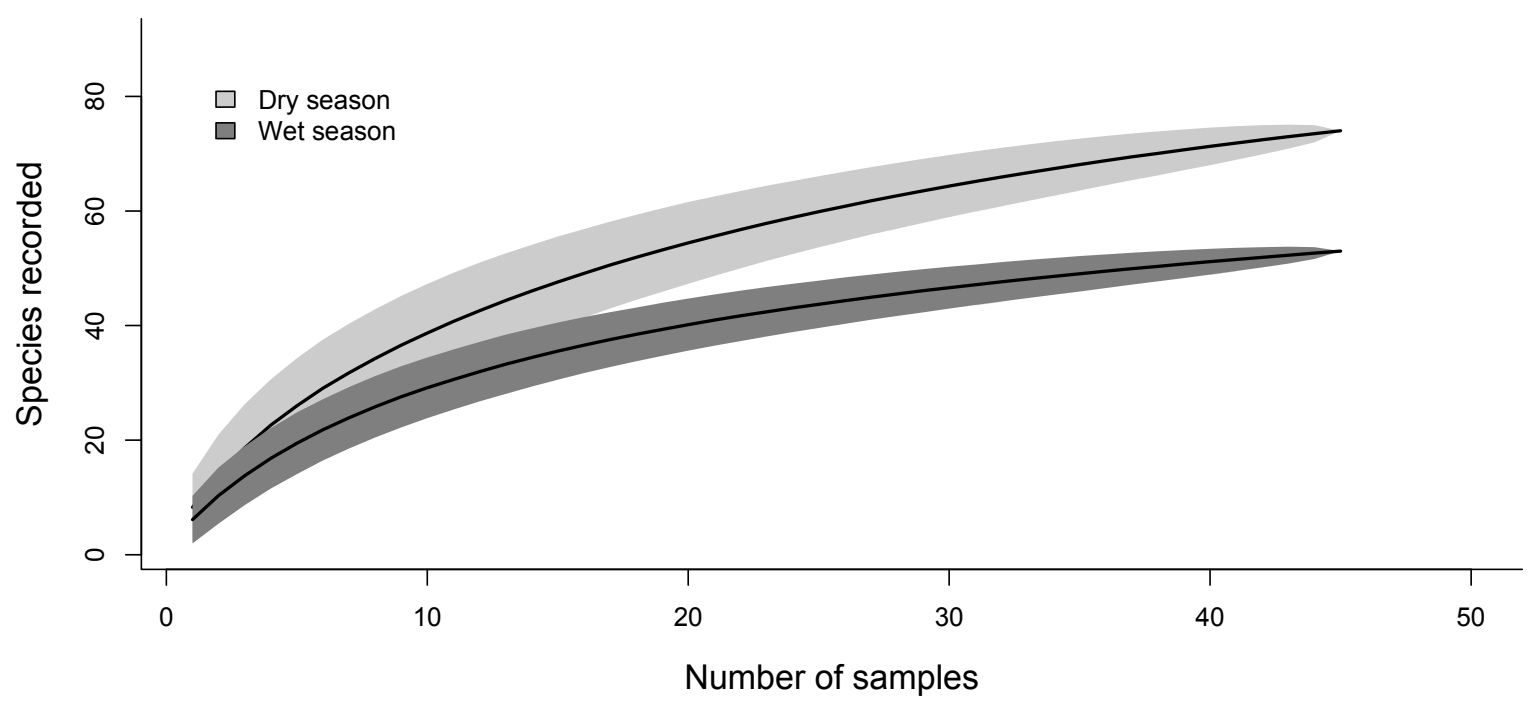

